\title{
Mr. Simpático: Dean Reed, Pop Culture, and the Cold War in Chile
}

\author{
JEDREK MULARSKI
}

\section{Introduction}

Dean Reed arrived in Santiago, Chile, for the first time in 1961. Reed had achieved only limited success as a rock and roll musician and film actor in the United States, but the Colorado native had become a celebrated teen idol in South America. When the blue-eyed North American came to Chile as part of his first South American tour, Reed's frenzied fans struggled during his performances to "touch him, give him surprise hugs, ruffle his hair, and even cut a piece of his jacket." ${ }^{1}$ Reed endeared himself to his Chilean fans and won over the Chilean media with his soft-spoken modesty and what the Chilean magazine Ercilla described as his demonstration of "what he is like in reality: a good North American fellow, inoffensive and naive, without ideas about anything besides rock." ${ }^{2}$ Reed's accessibility, his publicly stated affection for Chile, and his down-to-earth charm made him a pop culture darling of Chilean rock and roll fans and the Chilean media in the early 1960s.

Despite Reed's widespread popularity in Chile as a rock and roll idol in the 1960s, he became a controversial figure by the early 1970s. As Chileans became polarized by Cold War era tensions, both Reed and the Chilean public began to view the events and cultural representations of the era through an increasingly politicized lens. Unlike most North American stars, Reed in the 1970s was neither embraced by Chilean conservatives, who traditionally looked to the United States and Europe for their cultural influences, nor maligned by Chilean leftists, who often viewed pop culture from the United States as imperialist. Rather, as the United States collaborated economically, politically, militarily, and culturally with right-wing movements across Latin America to eliminate leftist political sentiment, Chile's conservative right aggressively attacked Reed and his music, while Chilean leftists gradually came to accept and work with Reed.

Scholars have traditionally emphasized the role that United States and Soviet actions played in Latin America during the Cold War, as both superpowers competed to expand their spheres of influence. This emphasis has been particularly prominent in studies on Chile, where scholars such as Stephen Rabe, Christopher Andrew, Lubna Qureshi, and Jonathan Haslam have focused on the impact of the United States and the Soviet Union in local politics. ${ }^{3}$ However, recent works on the Cold War era in Latin America have reconceptualized the conflicts of the period as the product of more diverse forces. For example, Hal Brands has argued that the Cold War was not a bipolar affair, but a combination of

\footnotetext{
1 "El rock con chaleco rojo," Ercilla, March 22, 1961.

${ }^{2}$ Ibid.

${ }^{3}$ See, among others: Stephen G. Rabe, The Killing Zone: The United States Wages Cold War in Latin America (New York: Oxford University Press, 2012); Christopher Andrew and Vasili Mitrokhin, The World Was Going Our Way: The KGB and the Battle for the Third World (New York: Basic Books, 2005); Lubna Qureshi, Nixon, Kissinger, and Allende: U.S.

Involvement in the 1973 Coup in Chile (Lanham: Lexington Books, 2009); Jonathan Haslam, The Nixon Administration and the Death of Allende's Chile: A Case of Assisted Suicide(London: Verso, 2005); and Stephen Kinzer, Overthrow: America's Century of Regime Change form Hawaii to Iraq (New York: Times Books, 2006).
} 
overlapping local, regional, and global conflicts. ${ }^{4}$ Similarly, Tanya Harmer's Chile and the Inter-American Cold War has argued that the Cold War in Latin America was not a "bi-polar superpower struggle projected onto a Latin American theater from outside," but a "unique and multisided contest between regional proponents of communism and capitalism, albeit in various forms."

As scholars have explored these multiple facets of the Cold War in Latin America, they have also started to consider the role that culture played in the tensions of this era. For example, In from the Cold: Latin America's New Encounter with the Cold War, edited by Gilbert Joseph and Daniela Spenser, examines how local social and cultural identities shaped the polarized conflicts of the era. ${ }^{6}$ Following such revisionist histories, this article examines the process by which Dean Reed became a polarizing figure in Chile as a means to reveal the complexities of Latin America's Cold War experience. Reed became part of an international cultural movement that was not simply the product of competition between the United States and the Soviet Union, but a more complex convergence of various political and cultural movements from across the Americas and beyond. The history of Dean Reed defies the traditional notion that resources and people flowed from the United States into Chile during the Cold War exclusively to advance right-wing efforts to suppress leftist movements. ${ }^{7}$ Moreover, it also provides a vivid example of rock and roll, a product of United States and European popular culture industries, being appropriated for anticapitalist purposes in the midst of the Cold War.

\section{Dean Reed and Chile in the 1960s}

Born in 1938 and raised in the Denver suburb of Wheat Ridge, Dean Reed started his collegiate education in meteorology at the University of Colorado in Boulder, before moving to California to pursue a career in show business. Between 1958 and 1961, Reed began a fledgling career as an actor and musician, earning a number of small roles in television and film, while also releasing several music albums with Capitol Records. Reed's work had not achieved widespread popularity in the United States, but his music was acquiring a tremendous following in South America, where "Our Summer Romance," Reed's upbeat single about teenage love, ascended to the top of Chile's popular music charts in 1959 and 1960, and where Reed shortly thereafter topped Elvis Presley in the South American Hit Parade Poll. ${ }^{8}$

Rock and roll arrived in Chile by the mid-1950s, and the music of Bill Haley and Elvis Presley completed a rapid transformation of Chile's musical scene from jazz and swing to rock and roll music from the United States and Europe. For many Chileans, the newest musical trends in the United States and Europe represented a cultural cosmopolitanism that Chile's middle-class consumer culture embraced. Music clubs became filled with the sounds of rock and roll, as did auditoriums and concert stages; Ricardo García, Julio Gutiérrez, and other popular disc jockeys broadcast the latest hits over Chile's largest radio networks, such as Radio Minería and Radio Cooperativa; television networks aired musical performances

\footnotetext{
${ }^{4}$ Hal Brands, Latin America's Cold War (Cambridge: Harvard University Press, 2010).

${ }^{5}$ Tanya Harmer, Allende's Chile and the Inter-American Cold War (Chapel Hill: University of North Carolina Press, 2011 ), 2. ${ }^{6}$ Gilbert Joseph and Daniela Spenser, eds., In From the Cold: Latin America's New Encounter with the Cold War (Durham: Duke University Press, 2008).

${ }^{7}$ As discussed in the conclusion of this article, Reed was not the only well-known U.S. citizen who spent time in Chile during the Allende era and expressed support for the Popular Unity movement. Other examples include Phil Ochs, Jerry Rubin, Stew Albert, David Ifshin, Marc Cooper, Country Joe McDonald, Saul Landau, James Beckett, and Nina Serrano.

${ }^{8}$ For biographies of Reed during his formative years and early career, see Chuck Laszewski, Rock ' $n$ ' Roll Radical: The Life and Mysterious Death of Dean Reed (Edina: Beaver's Pond Press, 2005); Reggie Nadelson, Comrade Rockstar: The Life and Mystery of Dean Reed, the All-American Boy Who Brought Rock 'n' Roll to the Soviet Union (New York: Walker and Company, 2006); and Ariana Harner, "Values in Conflict: The Singing Marxist," Colorado Heritage (1999): 14-25.
} 
by North American teen idols alongside Latin American pop musicians and crooners during prime time; and international recording companies seized the opportunity to promote and sell rock and roll records to middle and upper class youth at stores set up in Chile's well-to-do commercial districts. ${ }^{9}$

Rock and roll was not the only music that existed in Chile during this period. Older Chileans still listened to the "música típica" of groups such as Los Huasos Quincheros, rural Chileans and those who migrated from rural areas into Chile's larger cities enjoyed cumbias and Mexican rancheros, and a small group of progressive intellectuals were interested in non-commercial folk songs of Chile's outlying regions. ${ }^{10}$ Nonetheless, middle-class youth culture increasingly defined Chile's musical scene, and the Chilean mass media, which was controlled primarily by conservative business interests, embraced and contributed to this trend.

By the mid-1960s, Chilean rock and roll musicians had assimilated the imported sounds of rock and roll, and they existed alongside their United States and European counterparts; however, there remained among many Chilean music fans a preference for the "most authentic" rock and roll, which they considered to be music performed by United States and European artists or, at the least, music performed in English by Chileans who looked and acted like United States and European rock and rollers. ${ }^{11}$ Accordingly, when the tall, handsome, blue-eyed Reed arrived in Chile in 1961, he found a youthful, middle-class population eager to adopt what they perceived to be an "authentic" rock and roll star. Reed, who exhibited good-natured modesty, remained accessible to the media and fans and professed a love for Chile on his repeated visits to the country. He delighted the Chilean press with actions such as spontaneously dancing the cueca (Chile's national folk dance) with an admiring female fan and represented the perfect fit for this environment. ${ }^{12}$ The pop culture magazine Ecran wondered if Chileans would allow Reed to leave the country at the end of his March 1961 visit and in 1962 unofficially proclaimed him as the singer who received the most farewell events, including "despedidas" on Radio Minería (a station controlled by right-wing interests), Radio Portales (a station that would become one of the strongest supporters of the leftist Allende government), the Famae Stadium, and the (conservative) television Channel 13. ${ }^{13}$

While Reed garnered remarkable popularity among Chilean rock and roll fans during the early and mid-1960s, Chile was undergoing a period of political transformation that further diversified its musical landscape. As in many parts of Latin America, the persistence of socioeconomic inequities, United States intervention, and a growing belief in the possibility of meaningful social and political transformation had reenergized leftist politics in Chile. As part of this revolutionary fervor, leftists increasingly rejected mainstream pop music, arguing that it promoted passivity and consumerism. As Ariel Dorfman and Armand Mattelart explained in their 1971 essay, "Para leer al Pato Donald" ("How to Read Donald Duck"), Walt Disney and the United States pop culture industries created productions that were more

\footnotetext{
${ }^{9}$ Soledad Bianchi, “Música, noticias, alegría, no cambie el dial . ..," Cahiers du monde hispanique et luso-brésilien, no. 48 (1987): 149-52.

${ }^{10}$ Jedrek Putta Mularski, “Mexican or Chilean: Mexican Ranchera Music and Nationalism in Chile," Studies in Latin American Popular Culture 30, no. 1 (2012): 54-75. Also see Juan Pablo González, Claudio Rolle, and Oscar Ohlsen, Historia social de la música popular en Chile, 1950-1970 (Santiago: Ediciones Universidad Católica de Chile, 2009).

${ }^{11}$ Jedrek Putta Mularski, Music and Chile's Democratic Crisis: Song and the Formation of Political Identities, 1940-1973 (Ph.D. diss., University of California, San Diego, 2012). Also see David Ponce, Prueba de sonido (Santiago: Ediciones B, 2008); and González, Rolle, and Ohlsen, Historia social.

12 "Dean Reed cantó y bailó cueca en el 'te para diez'," Ecran, December 29, 1961.

13 "Dean Reed llega a Chile...टLL dejaremos irse?” Ecran, March 14, 1961. Also see "Dean Reed, el cantante más despedido del año," Ecran, December 25, 1962.
} 
than benign entertainment; rather, such productions reflected capitalist ideology and discretely promoted North American cultural values, such as the accumulation of individual wealth and United States superiority. ${ }^{14}$ Accordingly, many leftists wholeheartedly rejected the styles and sounds of rock and roll; others simply found little utility in the lovelorn lyrics of songs such as Reed's "Once Again" ("Once we were together and were oh so glad / Now you are gone from me / And I am oh so sad / For you are life to me / I love you so / Oh my dearest one / Why did I let you go?") or his rendition of "Donna Donna" ("Donna, Donna, why'd you want to do that / You led me on and lured me off / Then you turned me down flat / Donna Donna why'd you want to do that"). ${ }^{15}$

Rather than embracing the music of Reed and other rock and rollers, many Chilean leftists sought musical inspiration from what they believed to be more "authentic" expressions of the populace found in Latin America's folk traditions. During the second half of the 1960s, Chile became a gathering point for progressive-minded musicians from across Latin America. After returning from Paris with her son Ángel and her daughter Isabel in 1965, Violeta Parra opened the Peña de los Parra with the help of her children and other young Santiago folklorists, including Rolando Alarcón, Patricio Manns, and Victor Jara. It was a venue at which musicians could disseminate and popularize folkloric music from Chile and other regions of Latin America-sounds that had not yet found a place in Chile's commercial market. The Peña quickly became a gathering point for intellectuals, folklorists, and progressive-minded individuals, and it spurred the creation of other peñas in cities and at universities across Chile. Between 1966 and 1968, numerous new artists and peñas emerged and cultivated songs that drew on a wide array of folkloric influences and expressed increasingly strong social critiques. Left-leaning musicians such as Daniel Viglietti (Uruguay) and Atahualpa Yupanqui (Argentina) began to visit the peñas in other countries where similar folk-based movements had been underway for several years, and they did so increasingly as many South American governments stepped up efforts to repress left-wing activism. Chilean peña musicians also interacted and collaborated with socially progressive musicians such as Mercedes Sosa (Argentina), Chico Buarque (Brazil), Pablo Milanés (Cuba), and Silvio Rodriguez (Cuba) at regional music festivals with artists from across Latin America.

A principal outcome of the peñas and the interactions that they fostered was the development of what became known as the nueva canción ("new song”) movement. At its heart, the movement was a reaction against cultural imperialism and the commercial recording industry. The movement also strived to transcend Latin America's national boundaries through its desire for social justice, its valuation of the working classes, and a shared sense of cultural identity that drew heavily on the instrumentation, rhythms, melodies, and dress of the region's indigenous populations. ${ }^{16}$ In Chile, nueva canción became closely linked to the government of Salvador Allende, who won Chile's presidency in 1970 as the candidate of a leftist coalition known as Unidad Popular (Popular Unity). Utilizing government radio and television stations, music festivals, public performances, and start-up record labels, the Allende government worked with nueva canción musicians to further Unidad Popular's stated platform of advancing socialism by

\footnotetext{
${ }^{14}$ Armand Mattelart and Ariel Dorfman, Para leer el pato Donald (Buenos Aires: Siglo Veintiuno, 1972).

${ }^{15}$ Recordings of "Once Again" and "Donna Donna" are available at https://www.youtube.com/watch?v=mxTAzQUKCo0 and https://www.youtube.com/watch?v=TGrlRlyd-s4.

${ }^{16}$ For further background on nueva canción, see Jan Fairley, "La Nueva Canción Latinoamericana," Bulletin of Latin American Research 3, no. 2 (1984): 107-15; Jeffrey F. Taffet, “My Guitar is Not for the Rich': The New Chilean Song Movement and the Politics of Culture," Journal of American Culture 20, no. 2 (1997): 91-103; and Mularski, Music and Chile's Democratic Crisis. Examples of music and performances by nueva canción musicians Quilapayún, Victor Jara, and Inti-Illimani, are available at: https://www.youtube.com/watch?v=OxnARSurEiA, https://www.youtube.com/watch?v=52Rvas3PBjQ and https://www.youtube.com/watch?v=u0iBuNKUMcY.
} 
"fighting against cultural deformations of capitalist society." At the same time, Chile's right wing attempted to assert its control over mass media outlets and continue the dominance of commercial popular music while preventing the dissemination of nueva canción. ${ }^{17}$

\section{Dean Reed and Unidad Popular}

The nueva canción movement was not fully dogmatic in its rejection of musical influences from the United States and Europe. In fact, in certain instances, nueva canción musicians appropriated folk songs from the United States, such as "If I Had a Hammer," and they even collaborated with some progressive Chilean rock groups during the early 1970s. However, the heart of the movement was rooted in the influences of folk music from around Chile and other areas of Latin America, which makes Dean Reed's association with nueva canción artists and the Unidad Popular government particularly striking.

Accounts of Reed's life indicate that he possessed a strong social conscience from the start of his career. Anecdotes suggest that Reed got his start in the music business in the late 1950s after he picked up, clothed, and lodged a hitchhiker who ended up having a contact at Capitol Records, where Reed signed after moving to California. ${ }^{18}$ Accounts of Reed's early time in South America indicate that Reed was deeply affected by the level of poverty that he witnessed abroad. As Jorge Oñate, a public relations executive for EMI-Odeon (Capitol Records) in Chile recalled, when Reed saw Santiago's shanty towns, "He felt the suffering of others as his own, and kept telling me 'I can't believe that they live like this.",19 Reed's interviews from the early 1960s support such anecdotes, as Reed openly expressed his beliefs that "all human beings are the same" and actively voiced his support for the Civil Rights movement in the United States. ${ }^{20}$ Reflecting back on his political development, Reed asserted in 1970, "When I came to Chile the first time, I already had my beliefs. In those years I had refused to become a soldier, and I participated in the pacifist movement." ${ }^{21}$ Subsequently, Reed wrote specifically that the poverty that he observed after his arrival in South America sharpened his concern for social justice:

I remember exactly how I drove past the edge of the slums of Santiago on my trip to the beaches of the Pacific. In this section, consisting of shacks, naked misery ruled. There, children stood on the edge of the street, barefoot, with torn shirts and bloated stomachs, the unmistakable signs of insufficient nutrition. . . I I began to reflect at this time. There was the safe world of modern cities; there were the slums. There was the officially strong friendship with my homeland and there were the 'Yankee-go-home' calls. But, more and more questions gnawed at me. ${ }^{22}$

The Chilean public experienced periodic tastes of Reed's social conscience, including a highly publicized episode in April 1962, when Reed paid for a newspaper advertisement that urged Chileans to

\footnotetext{
${ }^{17}$ See Unidad Popular, Programa básico de gobierno de la Unidad Popular (Santiago: Impresora Horizonte, 1970) and Mularski, Music and Chile's Democratic Crisis.

${ }^{18}$ Nadelson, Comrade Rockstar, 27-29; Harner, "Singing Marxist." Also see "Dean Reed fue lanzado a la fama por un hombre pobre y sin trabajo," Mi Vida(1962). [The last reference may need a more complete date if it's a newspaper or magazine or other bibliographic data if it's another kind of reference.]

19 "El gringo que quiso ser Victor Jara," The Clinic, April 2008.

20 "Mañana es el te con Dean Reed," Ecran, December 5, 1961; "Dean Reed también desfiló por los negros," Ecran September 24, 1963. Also, see Laszewski, Rock ' $n$ ' Roll Radical, which references numerous State Department memos and State Department appeals to Reed throughout his career.

21 "Dean Reed: El cine, las canciones y...la politica," E1 Musiquero, December 1970.

${ }^{22}$ Laszewski, Rock 'n' Roll Radical, 27.
} 
write letters to President Kennedy requesting the United States to halt atomic tests. ${ }^{23}$ Reed's advertisement drew the attention of the United States government, which warned Reed about behavior that painted the United States in a negative light and began monitoring his activities. ${ }^{24}$ Within Chile, Reed's behavior was far less controversial. Chile's pop culture media outlets celebrated many of Reed's charitable deeds, such as his attendance at benefits for earthquake victims and his visits to children's hospitals. ${ }^{25}$ In doing so, these outlets helped to cultivate a popular image of Reed not only as a great musician but also as the so-called "Mr. Simpático," who provided a positive role model for Chilean teens. Ecran, for example, celebrated Reed's "idealism" and "optimism" as "two essential ingredients for the youth." ${ }^{26}$ Additionally, as discussed previously in this article, the press declared in December of 1962 that Reed was the musician who had received the most Chilean "despedidas" (farewell events), including ones at the conservative Radio Minería and Channel 13.

The lack of concern over Reed's political behavior in the early 1960s may have been due in large part to the fact that even as Reed became more openly concerned with social issues, the music that he released during the early 1960s was virtually devoid of social content. His songs, which he often produced in both English and Spanish, generally dealt with teenage life and young love. For example, Reed's biggest hit, "Our Summer Romance," expressed the sadness of teenagers whose summer romance came to an end with the start of the school year:

Although the summer is gone

I'll try to carry on

Although you won't be near me

And when school is through

I'll still be loving you

For nine months can't be so long.

"Our Summer Romance" culminated with a traditional pledge of fidelity:

I love no one but you

My love belongs to you

Someday I hope to marry you. ${ }^{27}$

Reed's 1959 recording of "I Ain't Got You" also connected to middle-class teen life, as the first two stanzas referenced a variety of desirable consumer goods that were everything a male teenager could want, with the exception of the girl he admired:

I got an Ivy League suit

With a slim lapel

Jet black jacket

That rings up the bell

Bad motorcycle and a sports car too

Oh what ain't I got?

I ain't got you.

I got a pork pie hat

\footnotetext{
${ }^{23}$ Ibid, 35-36.

${ }^{24}$ Ibid, 36-38.

${ }^{25}$ See for example: "En favor de las victimas de Chile," Antena TV, April 20, 1965; "Dean Reed visitó a los niños del Hogar de Menores," El Musiquero, December 1970.

26 "Dean Reed, el muchacho idealista," Ecran, Suplemento, 1962.

${ }^{27}$ A video of Dean Reed singing “Our Summer Romance” is available at http://www.youtube.com/watch?v=fI0l-r0mlOE.
} 
With a snap down brim

Charcoal blazer with a corduroy trim

Whole lot of records and a Hi-Fi too

Oh what ain't I got?

I ain't got you. ${ }^{28}$

Through the mid-1960s, Reed's political views and his popular music became increasingly contradictory. Reed continued to release romantic songs about young love and rock and roll songs about girls and teen culture. At the same time, however, Reed's politics gradually shifted leftward.

Seeking new professional opportunities in 1964, Reed took up residence in Argentina, another country where he had become very popular, and subsequently he moved to Italy, traveling extensively all the while in Latin America and Europe, and always receiving much fanfare when he passed through Chile. His travels included tours and the production of songs behind the "Iron Curtain." His experiences in the Soviet bloc continued to alter his political perspectives and made him the target of suspicion in Argentina, where Reed's political outspokenness antagonized the Argentine right wing and caused Reed to be threatened, his home vandalized, his dog poisoned, and his bedroom shot up with bullets. The Argentine press questioned Reed's sincerity and speculated that he only desired Argentine citizenship so that the government could not deport him for being a Communist. ${ }^{29}$ Reed publically denied that he was a Communist and asserted, "my profession comes first and . . I do not consider myself a politician." Nonetheless, Reed's private writings indicate that his internal sentiments did not necessarily echo his public claims. In 1965, Reed praised life under a communist system in a letter to himself:

Probably my greatest surprise during my trip inside the Soviet Union was to find that in the Communist countries of Russia and Czechoslovakia I found the people have more liberty from fear of the future, they have liberty from fear of old age, liberty from fear of illness, from lack of work. They have liberty of fear from being cheated by their fellow man every day of their life. They dedicate [sic] his life to his art or his work, and does not have to dedicate his life to the making of money.... We must sit down and choose the better of two points of view always-it won't be the ideal, but it will be the better of two systems. ${ }^{31}$

In the late 1960s, Reed's music began to take a political turn. Reed's performances had already started to incorporate a wider variety of music that included songs with an emphasis on social issues and pacifism, but Reed now began to release more politically oriented recordings, such as the antiwar song, "The War Keeps On," and "Historia llama" (History Calls), a call for social activism and social justice. ${ }^{32}$ Such music, combined with Reed's tours in the Soviet bloc, his public protests in Italy against the Vietnam War, and his open letters condemning U.S. policies and supporting the Soviet political system, provided sufficient cause for the Argentine and Uruguayan governments to block Reed's entry into their respective countries in 1969.

Recent research on the Cold War era in Latin America has revealed strong linkages and collaborations among governments and political movements throughout the region; however, despite Reed's growing image as a radical outside Chile, this reputation does not appear to have extended to Chile

\footnotetext{
${ }^{28}$ A video of "I Ain't Got You" is available at https://www.youtube.com/watch?v=FuIF26IdLkA.

29 "Ya no soy comunista rechaza Dean Reed," Argentina, November 4, 1965; "Dean Reed quiere ser argentine," Gente, September 7, 1965.

${ }^{30}$ Ibid.

${ }^{31}$ Dean Reed, letter to self, September 22, 1965 (quoted in Harner, "Singing Marxist").

${ }^{32}$ A recording of "The War Keeps On" is available at https://www.youtube.com/watch?v=dON13 rEDSM.
} 
by $1969 .{ }^{33}$ The Chilean teenage popular culture magazine, Ritmo de la juvendud, seemed perplexed by Reed's expulsion from Argentina and surmised, "It seems that the only reason for the strange measures taken by the governments of Argentina and Uruguay is political, and yet the singer isn't known to have been involved in any political activities in recent years and has been totally dedicated to his artistic career." ${ }^{34}$ Ritmo de la juventud's article continued by recounting a story in which Reed risked his life in 1966 by climbing into a burning building to rescue an elderly neighbor near his residence in Argentina. ${ }^{35}$ Moreover, despite Reed's personal political beliefs, his experiences in the Communist bloc, and the increasing political content of his music, the Chilean left still viewed Reed with suspicion. His 1970 visit to Chile, however, began to alter Chileans' impressions of him.

Reed was excited by the momentum of Salvador Allende's presidential campaign and went to Chile in 1970 with the intent to support the Popular Unity movement and denounce the Nixon administration. After arriving in Chile, Reed produced two songs through EMI-Odeon, which had reoriented its business model after Allende's election to take advantage of the government's support for nueva canción music. The first release, "Las cosas que yo he visto" ("Things That I Have Seen"), combined a somber, slowtempo chorus that mused, "When will they learn / Before they do harm / To search for the truth throughout?" with spoken-word verses that called attention to violence and injustices around the world. In particular, the song placed a strong emphasis on the plight of the poor with spoken word lyrics such as, "I've seen a man / Because he was poor / Bow to another man" and,

I've seen many people with disease

And many times death did come

Just because the man was poor

And the doctor he wouldn't come. ${ }^{36}$

The second of these two 1970 releases, "Somos los revolucionarios" (We Are the Revolutionaries), protested social injustice with a strikingly different tone. "Somos los revolucionarios" had the sound of an uplifting, fast-tempo, mainstream pop anthem of the late 1960s, but Reed combined this seemingly mainstream song with positive, but assertively revolutionary lyrics: "We want justice and liberty / We are the revolutionaries / We will always defend peace and humanity." Most strikingly, Reed incorporated lyrics against the pop music backdrop that were defiantly Latin Americanist:

San Martín has shown us

Which path must be followed

And you also should fight

Build your destiny. ${ }^{37}$

\footnotetext{
${ }^{33}$ In particular, see Harmer, Allende's Chile.

34 "Nadie quiere a Dean Reed," Ritmo de la Juventud, August 1969.

${ }^{35}$ Ibid.

${ }^{36}$ The lyrics of the English and Spanish versions of the song differ; however, the corresponding stanzas contain the same general tone and message: "Cuándo el mundo al fin segará / Las flores que son del mal / Y solo germine al sol de la paz / Los que quiero sembrar, la verdad"; "He visto a un hombre pobre / Arrodillado ante un rico"; "Y a un hombre matar, creyendo purificarse." A video of Reed singing "Las cosas que he visto" (Spanish) is available at http://www.youtube.com/watch?v=VFIsMYDz5zs.

${ }^{37}$ The Spanish lyrics of these excerpts are as follows: "Queremos la justicia y la libertad / Somos los revolucionarios / Defenderemos siempre la paz y humanidad"; "San Martín ya nos mostró / Cuál rumbo hay que seguir / También tú debes luchar, / Tu destino construer." A sound recording of "Somos los revolucionarios" (Spanish and English) dubbed over a variety of Dean Reed footage is available at http://www.youtube.com/watch?v=KXczGYSH4po.
} 
"Somos los revolucionarios" was representative of Reed's outlook on social revolution. Just as Reed saw no contradiction in blending revolutionary and Latin Americanist lyrics with mainstream pop sounds, he also saw no contradiction in being a pop idol and embracing left-wing politics:

I realized that I have some kind of power, due to my 'Idol' condition. I became popular, but I can't deny myself commitments with the society. Each person has a weapon: a rifle, the cinema, a guitar, a pen, etc. Mine is art, and through it I try to get to the people with a message of peace and understanding. So, I can contribute from my side to make a Socialist Democratic System. ${ }^{38}$

In addition to Reed's production of "Las cosas que yo he visto" and "Somos los revolucionarios" during his 1970 visit to Chile, Reed also engaged in a dramatic political protest, highly controversial and widely publicized by the Chilean media, outside the United States Embassy in Santiago. Having alerted the press about his plans, Reed arrived at the gates of the United States Embassy in late August dressed in a turtleneck sweater and tweed blazer. With photographers crowded around him, Reed stood in front of the Embassy gates with a United States flag and made the following declaration:

To the Peoples of the World: This North American flag is dirty with the blood of thousands of Vietnamese women and children, who have been burned alive by bombs of napalm which are dropped from U.S. planes of aggression, for the sole reason that the Vietnamese Peoples want to live in peace and liberty with independence and self-determination. This North American flag is dirty with the blood of the Negro race of the United States who are assassinated in their beds while they sleep by the U.S. police forces as a policy of genocide for the sole reason that the Negro race wants to live with dignity and with full civil rights as United States citizens. This North American flag is dirty with the blood and pain of the American Indians who are forced to live in semi-concentration camps. This North American flag is dirty with the blood and tears of the missions of people of the majority of the countries of South America, Africa, and Asia who are forced to live in misery and injustice because the U.S. government supports the dictatorships which keep these people in bondage. This North American flag is dirty because the great principles of democracy and liberty on which it was founded have been betrayed by the United States Government. As a good United States citizen who loves his country enough to fight to correct its errors and injustices and to try to make it a great country not only materially and militarily, but morally and spiritually, here today in Santiago de Chile, I do symbolically wash the flag of my country, the United States of America. ${ }^{39}$

Completing his declaration, Reed proceeded to wash the United States flag in a bucket of water before police arrested him.

Reed's activism and his support for Popular Unity extended beyond these examples, as he performed at rallies, benefits, and workers organizations both before and after Allende's victory in September 1970. Reflecting on his experiences with the Popular Unity movement, Reed revealed a sincere commitment to Popular Unity's success, a deep disdain towards United States policy, and a complex sense of both national and transnational identity as a political agitator:

In Santiago, Chile, I sang at the voting rallies of the people's front. Nevertheless, I was much less a singer than an agitator. I considered myself to be an Internationalist; at the same time I was a patriot as I had never been before. For the Unidad Popular was for me a power that could put those people in the USA in their place, those who oppressed not only in Chile, but also in their own country. It was not coincidence that I had just decided at that time to

\footnotetext{
38 "Dean Reed: El Cine, las canciones y . . . la politica," E1 Musiquero, 1970.

${ }^{39}$ Laszewski, Rock 'n' Roll Radical, 122.
} 
demonstrate against the claims of world domination by the government of my country. The Chileans and all of the people in the world should see that the United States consists not only of Wall Street and the Pentagon, but also that it has citizens who take a stand for freedom and justice. $^{40}$

Despite Reed's claims to the contrary, many Chileans still questioned the sincerity of his song lyrics, public protests, and support for Popular Unity. Telecran, for example, wondered about the true motivations for Reed's political protests in the aftermath of his flag washing episode: "Are his expositions sincere, or are they just publicity stunts? He says no to the latter and that he is acting in accordance with his conscience. Should we believe him?" ${ }^{41}$ Similar questions surrounded Reed's acceptance of Allende's request that he perform at Allende's November 1970 inauguration celebration, which included numerous public performances by dozens of Chilean folklorists, nueva canción musicians, dance troupes, actors, poets, and other popular entertainers in the streets of the capital. ${ }^{42}$ One account of Reed's appearance at the inauguration by the United States Embassy asserted that Reed was "booed off the stage by the assembled populace" that presumably saw through Reed's "political stunts." ${ }^{43}$ Another account of Reed's performance claims that the presence of the tuxedo-clad Reed attracted many teenagers who had no affinity towards Allende, but who showed up at the inaugural festivities only because they wanted to see Reed and get his autograph; this account is particularly interesting in that it implies that even in the midst of heightening political tensions, polarization, and violence between the Chilean left and right, pop music still transcended political affiliations for many non-leftist Chilean teens. ${ }^{44}$

Musicians in Chile's nueva canción movement also viewed Reed with a degree of skepticism. Eduardo Carrasco, a member of the prominent nueva canción group Quilapayún, recalled the impressions that he and Victor Jara, another prominent nueva canción musician, had towards Reed: the two initially suspected that Reed's political antics were efforts at self-promotion. Gradually, they came to accept that Reed was sincere, albeit naïve:

His [Reed's] mentality was typical of show business: to craft his image, advertise himself. When he started getting close to us and to Victor [Jara], because he saw in us legitimate representatives of what was happening in South America, we suspected that he was trying to create a revolutionary image, to get the media's attention. [But] Dean was sincere ... in reality he was very naïve. He had a view about public affairs that was more based in ethics than reflexive and political. ${ }^{45}$

Whereas Reed saw no contradiction between being a pop idol and a revolutionary, Chilean leftists did not necessarily share Reed's belief. In fact, Reed never fully overcame the skepticism that he faced; even a recent critical biographical essay on Reed entitled "The Gringo Who Wanted to Be Victor Jara," which was published in 2008 by the left-leaning Chilean periodical The Clinic, critiqued the incompatibility of Reed's politics, his career, and his idol status. ${ }^{46}$ Nonetheless, Reed's efforts in support of Popular Unity did ultimately earn him a degree of acceptance within the movement, even if this acceptance had limits.

\footnotetext{
${ }^{40}$ Ibid, 121.

41 “Cuando Dean Reed protesta ... se anota," Telecran, September 20, 1970. (Ecran was reorganized as Telecran in 1969.)

42 "Fiestas populares," La Prensa, November 3, 1970.

${ }^{43}$ Harner, "Singing Marxist."

44 "El gringo que quiso ser Victor Jara," The Clinic, April 2008.

${ }^{45}$ Ibid.

${ }^{46}$ Ibid.
} 


\section{Reed and the Chilean Right}

While Chilean leftists were reluctant to accept the idea of Reed as a revolutionary, the Chilean right altered its impression of Reed more quickly, as Reed's political outspokenness within Chile escalated. The Chilean right viewed Allende's election not only as an attack on their political and economic liberties, but also as the product of foreign agitators. The idea that left-wing ideologies were being imported to Chile from other countries had deep roots, as the right had blamed outside influences for outbreaks of labor unrest back in the nineteenth century. ${ }^{47}$ The level of fear and anxiety about the importation of left-wing ideologies and agitators reached new heights during the Cold War, particularly after Allende cultivated a relationship between Chile and Cuba.

In early 1971, Reed performed at the Viña del Mar Music Festival, Chile's largest music festival and a festival with a reputation for having a heavily conservative middle and upper class audience. The inclusion of Reed and Cuban singer Elena Burke at the festival upset many Chilean rightists, and festival attendees gave Reed a particularly cold reception when he took the stage. In its coverage of the festival, the right-wing newspaper El Mercurio emphasized that the audience castigated Reed for his objectionable, political performance. Emphasizing the "tall and blond showman's" foreign background, El Mercurio chastised both his "dull" routine and his superficial efforts to relate to the audience as "huasitas" or "huasitos" (cowboys and cowgirls of Chile's central valley) with his marked American accent. It reported that Reed's "songs with [political] messages" drew little support from the crowd and that he received only scattered applause after he eventually returned to his traditional selection of English-language songs. ${ }^{48}$

El Mercurio's coverage of Reed's performance at Viña del Mar reveals that by 1971, the Chilean right's perspective on Reed was shifting from viewing him as a representation of cultural cosmopolitanism and consumer culture to viewing him as a foreign agitator who assaulted Chile's national traditions and sensibilities. In the context of rising right-wing fears of communist influences from abroad, increasing right-wing resentment towards what it viewed as "politicized" nueva canción music, and Reed's growing outspokenness, the Chilean right was turning against Reed by stressing his "foreignness." By defining Reed in these terms, El Mercurio implied that his foreign, leftist music had no place among true "huasitas" and "huasitos," with whom Reed, over whom the Chilean press had once gushed when he had learned Spanish and again when he danced a Chilean cueca with an admiring fan, could not identify. ${ }^{49}$

Other articles about Reed in the conservative press reinforced these perceptions by referring to Reed as the "North American . . known for insulting the flag of his homeland" and for his "loyalty to Marxism," as well as by explicitly categorizing Reed's music and nueva canción music together as "protest songs" that had no "artistic quality" and "irritated the [Chilean] public." ${ }^{50}$ The conservative newspaper $\mathrm{La}$ Segunda went so far as to make Reed the center of its efforts to condemn the C.U.T. (Central Unitaria de Trabajadores de Chile) Union Federation's Competition of Revolutionary Song in 1972 by stating sarcastically that two requirements for being the judge of the competition were to "be a friend of Dean Reed and bring him to the event in case some money is made," and to make sure that "the collected money should not be awarded, but given to Dean Reed, who is the organizer and won by his own merits

\footnotetext{
${ }^{47}$ See, for example, Michael Monteón, “The British in the Atacama Desert: The Cultural Bases of Economic Imperialism,” The Journal of Economic History 35, no. 1 (1975): 117-33.

48 "Público protesta por folklore comprometido," El Mercurio, March 9, 1971.

${ }^{49}$ Among the various criticisms of Reed in the aforementioned 2008 article in The Clinic was a jab at Reed for singing a Victor Jara song with an accent that sounded like the "Spanish of Miami"; just as the right unleashed nationalist attacks on Reed's foreignness during the Allende era, more recent critics from the left have similarly attacked Reed's foreignness.

50 "Festival de la Canción," El Mercurio, February 20, 1971.
} 
the concession of all funds from this area." ${ }^{, 1}$ By casting Reed as an outsider, firebrand, and opportunist, while simultaneously linking him with leftist musicians, the conservative press implied that the political nueva canción music sung by Chilean artists was similarly imported propaganda that left-wing rabblerousers used to dupe the populace. Moreover, by targeting a North American, El Mercurio countered the left's anti-imperialist discourse, which characterized the right as political pawns of the United States and slaves to its cultural hegemony.

In effect, Reed epitomizes the cultural complexities of the Cold War era in Chile. On the one hand, Chilean leftists and the nueva canción movement worked to cultivate shared cultural expressions with folk-based musicians from across Latin America and beyond, but they also viewed Reed with a skeptical eye on account of his ties to United States-influenced pop music. On the other hand, conservatives, who had long embraced foreign pop music from the United States and Europe as expressions of cultural cosmopolitanism, ultimately rejected the formerly beloved Reed as a foreigner who could not relate to Chile's own realities. In the years after a right-wing military coup overthrew Salvador Allende's government in 1973, Reed settled in East Germany and frequently performed for his many fans throughout the Soviet bloc. In 1983, Reed returned to Chile, where he held several concerts to protest the Pinochet dictatorship before the Chilean government expelled him. Three years later, Reed was found dead in a lake near his Berlin home. While officials determined Reed's death to be either a suicide or an accidental drowning, journalists, biographers, and friends have speculated that he was assassinated by right- or left-wing forces. Such speculations have fingered the United States, whose government Reed had antagonized for years; East Germany, whose policies Reed had critiqued increasingly and who perhaps objected to Reed's desire to rekindle his career in the United States; and even Israel, whose government objected to Reed's increasing professions of support for Palestinian rights. ${ }^{52}$ Such theories reveal that, as he had in life, Reed continued in death to demonstrate the multifaceted nature of the Cold War era, demonstrating the difficulty of conceptualizing the events of that period in binary terms.

\section{Conclusion}

The history of Dean Reed in Chile illustrates the complex dynamics of the Cold War era in Latin America. Above all, Reed's image as an internationalist, his constant movement between countries and peoples, and the various local influences that he assimilated demonstrate that the political struggles of the period were more than just manifestations of conflicts between capitalism and communism projected onto Latin America by the United States and the Soviet Union. Although Reed's story is exceptional, his experience of having been raised in the United States and then becoming active in the Popular Unity movement contradicts the idea that the flow of money, ideas, influences, and political and military support from the United States into Chile was exclusively anticommunist in nature. While the United States government exerted great effort to undermine Allende's presidency, there were also North American activists who directly supported Allende. For example, in addition to Reed, North American folk singer Phil Ochs spent time in Chile during the Allende era, becoming a strong supporter of the Popular Unity movement and developing a relationship with Victor Jara. ${ }^{53}$ Yippie leaders Jerry Rubin and Stew Albert,

\footnotetext{
51 “Aires y efluvios populares en festival revolucionario," La Segunda, March 17, 1972.

${ }^{52}$ Ivan Witker, "El Caso Honecker, el interés nacional y la política esterior de Chile," Estudios Públicos (Summer 2007): 24849.

${ }^{53}$ See Michael Schumacher, There But for Fortune: The Life of Phil Ochs (New York: Hyperion, 1996). It should also be noted that several months after a military coup overthrew Allende's government and executed Victor Jara, Ochs organized
} 
along with David Ifshin, also visited Chile in 1971 to observe and support Popular Unity, while California native Marc Cooper moved to Chile after Salvador Allende's election and became the Chilean President's translator. ${ }^{54}$ Additionally, musician Country Joe McDonald and filmmakers Saul Landau, James Beckett, and Nina Serrano went to Chile to film iQue hacer! against the backdrop of Allende's election, and Landau also produced Conversation with Allende in $1971 .^{55}$

Beyond these revealing implications, Reed's time in Chile provides ample evidence for the significant role that culture can play in political conflict. Reed, as a rock and roll musician with leftist political convictions, shared a North American pop culture aesthetic with many on the Chilean right, but a political orientation linked most closely to Chilean leftists. As political tensions in Chile escalated, the Chilean right turned against Reed, in part as a means to counter leftist claims that rightists were pawns of the United States, but principally because the political perspectives that Reed voiced, both through his public activism and increasingly through his song lyrics, overshadowed the affinity that they felt for North American-influenced pop culture. At the same time, many leftists were skeptical of Reed, as they viewed him less according to his public activism and the political lyrics of his songs, and more according to the pop culture ideology embedded in his appearance and in the musical properties of his songs. Accordingly, even though Reed's political positions coincided with many of the platforms championed by the Popular Unity government, his image as a pop icon did not fit with Popular Unity's cultural nativism or the more orthodox belief that imperialist ideologies and capitalist impulses were inherently embedded in all North American-influenced pop music. Set against the backdrop of Chile's intense political polarization and the Allende government's struggle to retain political power, Dean Reed's political activism and the overtly political lyrics of his songs ultimately won him a degree of acceptance within the Popular Unity movement.

Reed's history in Chile demonstrates the complex and shifting relationship of music to politics. As Susan McClary has argued about the communication of ideology through music, "The formal mechanisms that emerge in repertories are to a large extent the means by which views of the world and values find themselves articulated. Thus, in order to explain adequately the history of musical repertories and their formal strategies, involvement with meaning-both expressive and ideological—is essential." ${ }^{, 56}$ Reed and his music communicated multiple ideological orientations through his appearance, his reputation, his song lyrics, and the musical properties of his songs. The study of Dean Reed in Chile demonstrates that these elements may or may not act in unison, and depending on the person interpreting the song and the context in which the song is being interpreted, each component may become more or less significant than the others. In this manner, Dean Reed and his music provide a vivid example of the complex and overlapping dynamics that shaped the trajectory of Chile's Cold War experience.

\footnotetext{
“An Evening With Salvador Allende: The Friends of Chile Benefit," a concert that condemned the coup and raised support for Chilean refugees at the Felt Forum of New York's Madison Square Garden. The concert included performances by Ochs, Pete Seeger, Arlo Guthrie, Melanie, Dave Von Ronk, Mike Love and Dennis Wilson, Dennis Hopper, and Bob Dylan. For further details of this event, see Hank Reineke, Arlo Guthrie: The Warner/Reprise Years (Lanham: Scarecrow Press, 2012) and Claudio Vergara "La noche que Bob Dylan le cantó a Allende," La Nación, no. 31 (August 2003).

${ }^{54}$ See for example: "La revolución peluda," Ahora, 1971. For further information on Marc Cooper, see Cooper's book, Pinochet and Me: A Chilean Anti-Memoir. (London: Verso, 2001).

${ }_{55}$ iQue Hacer! is available at http://www.youtube.com/watch?v=FQzCkmHirFk.

${ }^{56}$ Reading Music: Selected Essays (Burlington: Ashgate, 2007), 10.
} 


\section{Bibliography}

Andrew, Christopher, and Vasili Mitrokhin. The World Was Going Our Way: The KGB and the Battle for the Third World. New York: Basic Books, 2005.

Bianchi, Soledad. "Música, noticias, alegría, no cambie el dial . ." Cahiers du monde hispanique et lusobrésilien, no. 48 (1987): 149-53.

Brands, Hal. Latin America's Cold War. Cambridge: Harvard University Press, 2010.

Cooper, Marc. Pinochet and Me: A Chilean Anti-Memoir. London: Verso, 2001.

"El gringo que quiso ser Victor Jara." The Clinic, April 2008.

Fairley, Jan. "La Nueva Canción Latinoamericana.” Bulletin of Latin American Research 3, no. 2 (1984): 107-15. http://dx.doi.org/10.2307/3338257

González, Juan Pablo, Claudio Rolle, and Oscar Ohlsen. Historia social de la música popular en Chile, 1950-1970. Santiago: Ediciones Universidad Católica de Chile, 2009.

Harmer, Tanya. Allende's Chile and the Inter-American Cold War. Chapel Hill: University of North Carolina Press, 2011.

Harner, Ariana. "Values in Conflict: The Singing Marxist." Colorado Heritage (1999): 14-25.

Haslam, Jonathan. The Nixon Administration and the Death of Allende's Chile: A Case of Assisted Suicide. London: Verso, 2005.

Joseph, Gilbert, and Daniela Spenser, eds. In From the Cold: Latin America's New Encounter with the Cold War. Durham: Duke University Press, 2008.

Kinzer, Stephen. Overthrow: America's Century of Regime Change form Hawaii to Iraq. New York: Times Books, 2006.

Laszewski, Chuck. Rock 'n' Roll Radical: The Life and Mysterious Death of Dean Reed. Edina: Beaver's Pond Press, 2005.

Mattelart, Armand, and Ariel Dorfman. Para leer el pato Donald. Buenos Aires: Siglo Veintiuno, 1972.

McClary, Susan. Reading Music: Selected Essays. Burlington: Ashgate, 2007.

Monteón, Michael. "The British in the Atacama Desert: The Cultural Bases of Economic Imperialism." The Journal of Economic History 35, no. 1 (1975): 117-33. http://dx.doi.org/10.1017/S002205070009433X

Mularski, Jedrek Putta. Music and Chile's Democratic Crisis: Song and the Formation of Political Identities, 1940-1973. Ph.D. diss., University of California, San Diego, 2012.

- "Mexican or Chilean: Mexican Ranchera Music and Nationalism in Chile." Studies in Latin American Popular Culture 30, no. 1 (2012): 54-75. http://dx.doi.org/10.1353/sla.2012.0015

Nadelson, Reggie. Comrade Rockstar: The Life and Mystery of Dean Reed, the All-American Boy Who Brought Rock ' $n$ ' Roll to the Soviet Union. New York: Walker and Company, 2006.

Ponce, David. Prueba de sonido. Santiago: Ediciones B, 2008.

Qureshi, Lubna. Nixon, Kissinger, and Allende: U.S. Involvement in the 1973 Coup in Chile. Lanham: Lexington Books, 2009.

Rabe, Stephen G. The Killing Zone: The United States Wages Cold War in Latin America. New York: Oxford University Press, 2012.

Reineke, Hank. Arlo Guthrie: The Warner/Reprise Years. Lanham: Scarecrow Press, 2012. 
Schumacher, Michael. There But for Fortune: The Life of Phil Ochs. New York: Hyperion, 1996.

Taffet, Jeffrey F. "'My Guitar is Not for the Rich: The New Chilean Song Movement and the Politics of Culture." Journal of American Culture 20, no. 2 (1997): 91-103. http://dx.doi.org/10.1111/j.1542734X.1997.00091.x

Unidad Popular. Programa básico de gobierno de la Unidad Popular. Santiago: Impresora Horizonte, 1970.

Vergara, Claudio. "La noche que Bob Dylan le cantó a Allende.” La Nación, no. 31 (August 2003).

Witker, Ivan. "El Caso Honecker, el interés nacional y la política exterior de Chile." Estudios Públicos (Summer 2007): 241-65. 